\title{
LIST OF BIRDS COLLECTED BY WILLIAM T. FOSTER IN PARAGUAY.
}

\author{
By Harry C. Oberholser, \\ Assistant Ornithologist, Department of Agriculture.
}

The collection of Paraguay birds sent by Mr. William T. Foster to the United States National Museum, though small, is of more than casual interest. It consists of 78 specimens, representing 65 species and subspecies, several of which appear to be heretofore unrecorded from Paraguay; while Blacicus pileatus, Myiopagis caniceps, Phyllomyias salvadorii, and Cyanocorax heckelii are of sufficient rarity to be worthy of special mention. Further than this, there are seven biras (four species and three subspecies) that seem to be new to science; and of these preliminary descriptions have already been published. ${ }^{1}$ Matter between quotation marks in the following list is from the notes of the collector.

Sapucay, Paraguay, whence come these specimens, is situated a short distance east of the city of Asuncion, thus somewhat south of the central portion of the country.

The subjoined notes are presented at the instance of Mr. Ridgway, curator of the division of birds, to whom and to Dr. Charles W. Richmond the writer is indebted for many kindnesses. To the authorities of the American Museum of Natural History, for the loan of specimens, due acknowledgment should here be made.

\section{Family BUCCONID A.}

\section{BUCCO CHACURU Vieillot.}

Bucco chacuru Vieiliot, Nouv. Dict. d'Hist. Nat., III, 1816, p. 239.

One adult female. "Iris brownish white." In this species there seems to be much individual difference in the depth of the buffy tinge on the lower surface and on the collar; in some specimens these parts are almost pure white, in others deep ochraceous.

\footnotetext{
${ }^{1}$ Proc. Biol. Soc. Wash., XIV, 1901, p. 187.
} 


\section{Family PICID A.}

\section{VENILIORNIS SPILOGASTER (Wagler).}

Picus spilogaster W AgLer, Syst. Avium, 1827, Picus, sp. 59, p. 33.

Veniliomis spilogaster Oberholser, Proc. Acad. Nat. Sci. Phila., 1899, p. 205.

One adult female, seemingly identical with a specimen taken at Buenos Ayres. "Iris browny red."

\section{PICUMNUS CIRRATUS Temminck.}

Picumnus cirratus Temminck, Pl. Col., IV, 1825, pl. cCclxxi, fig. 1.

One specimen, apparently immature, and differing from the adult in the duller shade of back and scapulars. "Iris brown."

\section{Family FORMICARIIDA.}

\section{HERPSILOCHMUS RUFIMARGINATUS (Temminck).}

Myothera rufimarginata Теммплск, Pl. Col., II, 1822, pl. cxххі, figs. 1, 2.

Herpsilochmus rufomarginatus Ca Banis, Wiegmann's Archiv f. Naturg., 1847, Pt. 1, p. 224 .

One adult male, June 27, 1900. "Iris brown." The back of this specimen has considerable admixture of black. Temminck's original description of Myothera mifimarginata, ${ }^{1}$ and Maximilian's Myiothera scapularis ${ }^{2}$ represent a bird without black on the back; while Myiothera variegata Maximilian ${ }^{3}$ is said to differ in having black on some of the dorsal feathers. Unless this be a difference due to age or individual variation - apparently an unlikely hypothesis - there are probably two species now confused under the name Herpsilochmus rufimarginatus, one of which should stand as Herpsilochmus variegatus (Maximilian). Sufficient material to settle the question we have not available.

\section{DYSITHAMNUS MENTALIS (Temminck).}

Myothera mentalis Temminck, Pl. Col., II, 1823, pl. clxxix, fig. 3.

Dasythamnus mentalis Burmeister, Syst. Ueber. Vög. Bras., III, 1857, p. 82.

One adult male, in perfect plumage and entirely typical. "Iris brown.'

In a comparatively recent paper Dr. Allen ${ }^{4}$ has united under this species both Thamnophilus olivaceus Tschudi ${ }^{5}$ and Dysithamnus semicinereus Sclater, ${ }^{6}$ following to ultimate end the doubt expressed by Dr. Sclater regarding the distinctness of the last. ${ }^{?}$ True Dysithammus

\footnotetext{
${ }^{1} \mathrm{Pl}$. Col., II, 1822, pl. cxxxII, figs. 1, 2.

${ }^{2}$ Beitr. Naturg. Bras., III, 1830, p. 1083.

${ }^{3}$ Idem, p. 1086 (Lichtenstein manuscript).

${ }^{4}$ Bull. Amer. Mus. Nat. Hist., V, 1893, p. 118.

Faun. Per., Aves, 1845-46, p. 174, pl. xi, fig. 1.

${ }^{6}$ Proc. Zool. Soc. Lond., 1855, pp. 90, 147, pl. xcvir.

${ }^{7}$ Cat. Birds. Brit. Mus., XV, 1890, p. 221.
} 
mentalis, according to Temminck's original plate and description, with which the above mentioned Paraguay specimen perfectly agrees, is uniform dull grayish olive green on all the middle and posterior upper parts, this color being trenchantly defined against the plumbeous of head and cervix; the throat is grayish white, giving way rather abruptly to the clear naples yellow of breast and abdomen. But Dysithammus olivaceus is apparently quite a distinct species, the male differing from that of $D$. mentalis in being usually quite uniform plumbeous above, and though sometimes appreciably tinged with olive, principally on the rump, never-olive green; the lower surface posterior to the throat is never clear yellow, but generally white medially, much shaded with slate gray laterally, and on flanks and crissum tinged with pale brownish, ochraceous, or yellowish. The same large series which Dr. Allen studied has been examined in the present connection; and a considerable number of additional specimens in the United States National Museum, principally from Colombia and Central America, have thrown light upon the questions involved. Two forms of $D$. olivaceus are readily recognizable, $D$. olivaceus olivaceus from Peru, Bolivia and western Brazil, and D. olivaceus semicinereus from Colombia and Central America. While it is true that there are absolutely no valid characters by which the males of these two forms can be separated, there is no difficulty at all in distinguishing the females, for those of semicinereus are very much darker both above and below, specimens from Colombia (Bogota) being extreme in this particular.

With regard to the proper names for these two forms there is, unfortunately, some room for question. The point to be determined is the identity of Tschudi's name olivaceus, which from plate and description might apply to either the Brazilian or Central American bird. The present separation of olivaceus and semicinereus is based on comparison of specimens from Matto Grosso, Brazil, which are considered to represent olivaceus, with examples from Bogota, the type locality of semicinereus; while none from Ecuador, Peru, or Bolivia have been available. Should Peruvian specimens prove olivaceus identical with semicinereus, the latter would, of course, become a synonym, and another subspecific name would be necessary for the bird of western Brazil, which undoubtedly would be affinis Pelzeln. ${ }^{1}$ Although strongly inclined to the belief that this will some day have to be done, we refrain from making such a change until absolute proof of the necessity be obtained.

THAMNOPHILUS C ÆRULESCENS Vieillot.

Thamnophilus cxrulescens VierLlot, Nouv. Dict. d'Hist. Nat., III, 1816, p. 311.

A single adult male in perfect plumage is apparently typical. "Iris brown.'

${ }^{1}$ Orn. Bras., 1869, pp. 80, 149.

Proc. N. M. vol. $\mathrm{xxv}-02-9$ 


\section{THAMNOPHILUS OCHRUS Oberholser.}

Thamnophilus ochrus OBerholser, Proc. Biol. Soc. Washington, XIV, 1901, p. 188.

Chars. sp.-Female resembling that of Thamnophitus cærulescens, but rather lighter, more grayish above; the lesser wing-coverts black instead of olivaceous; the entire ventral surface decidedly paler, the breast grayish buff, the central portion of abdomen buffy white.

Description.-Type, adult female, No. 173378, U.S.N.M.; Sapucay, Paraguay, June 24, 1900; William T. Foster. Upper parts grayish olive brown, more brownish on the scapulars and on the crown, the fore part of which latter is lighter; the feathers of the center of the back with large ill-concealed white spots usually in the form of broad irregular bars, succeeded distally by a more or less evident subterminal mark of blackish; middle tail-feathers similar to the general tone of the back, though rather darker, unmarked with white, the remaining rectrices brownish black, margined with brownish slate, and tipped with white, the outer pair with also a white bar about 7 millimeters wide near the middle of the external web; wing-quills fuscous, edged exteriorly with olive brown; all the superior coverts black tipped with white, the greater series margined basally with grayish olive brown; lores, cheeks, and eye ring grayish white, much mixed with grayish olive; sides of neck and head behind the eyes grayish olive, the auriculars rather darker with shaft lines of buffy white; chin and throat grayish white mixed with dusky and very faintly washed with ochraceous; breast grayish buff-or better, dull pale gray washed with ochraceous buff; sides, flanks, and crissum plain ochraceous, the center of abdomen and lower breast dull buffy white; under wing-coverts and inner margins of wing-quills buffy white; axillars buffy ochraceous. Bill brownish black, the base of mandible paler; "iris brown." Length of wing, $70 \mathrm{~mm}$; tail, $65 \mathrm{~mm}$.; exposed culmen, $12 \mathrm{~mm}$; height of bill at base, $5.5 \mathrm{~mm}$; tarsus, $23.5 \mathrm{~mm}$., middle toe, $13 \mathrm{~mm}$.

Only a single specimen, the female above described, was obtained by $\mathrm{Mr}$. Foster, but this apparently differs so greatly and in so many respects from the same sex of all allied species that it seems undoubtedly to represent a form hitherto undescribed. It seems to be nearest Thamnophitus cremlescens in size and proportions, and in these respects scarcely exhibits material difference, though in color it is of quite other appearance, as above set forth. The only other species with which it seems to have at all close affinity is Thamnophilus aspersiventer d'Orbigny and Lafresnaye, ${ }^{1}$ from Yungas, Bolivia, but judging from the various descriptions of this latter, the female of Thamnophitus ochrus is very much paler below, having a broad buffy white area on

${ }^{1}$ Synopsis Avium, I, 1837, p. 10; d' Orbigny, Voyage Amer. Mérid., IV, Ois., 1835-44, p. 171, pl. Iv, figs. 1 and 2. 
the lower breast and in the center of the abdomen, sharply contrasted to the ochraceous of sides and flanks; also the bill of ochrus is of smaller size.

There are apparently no synonyms that apply to this new species, for Thamnophilus pileatus Swainson ${ }^{1}$ is clearly not the same, if indeed at all with certainty identifiable; and Thamnophilus ventralis Sclater ${ }^{2}$ is undoubtedly the Thamnophilus cxrulescens of Vieillot. Furthermore the Thamnophitus auratus of Vieillot ${ }^{3}$ does not correspond with the bird sent by Mr. Foster, and quite surely is the female of T. cærulescens.

\section{THAMNOPHILUS RADIATUS Vieillot.}

Thamnophilus radiatus Vieinlot, Nouv. Dict. d' Hist. Nat., III, 1816, p. 315.

The single adult female is apparently typical of this species. "Iris buff."

\section{HYPOEDALEUS GUTTATUS (Vieillot).}

Thamnophilus guttatus Vieillot, Nouv. Dict. d'Hist. Nat., III, 1816, p. 315.

Hypoedaleus guttatus Cabanis and Herne, Mus. Hein., II, 1859, p. 18.

One adult male, seemingly indistinguishable from a specimen taken in Rio Grande do Sul, Brazil. "Iris brown."

This species differs so greatly in the shape of the bill and length of tail from the typical forms of Thamnophilus that there seems to be excellent reason for the generic separation proposed by Cabanis and Heine, ${ }^{4}$ and here adopted.

\section{Family DENDROCOLAPTID A.}

\section{PICOLAPTES TENUIROSTRIS APOTHETUS Oberholser.}

Picolaptes tenuirostris apothetus OBerholser, Proc. Biol. Soc. Washington, XIV, 1901, p. 188.

Chars. subsp.-Similar to Picolaptes temirostris tenuirostris, but very much smaller, and with the pale shaft streaks of the back decidedly more narrow.

Description.-Type, adult male, No. 173385, U.S.N.M.; Sapucay, Paraguay, June 16, 1900; William T. Foster. Upper parts olive brown, the back more reddish, the rump and upper tail-coverts chestnut; head thickly spotted with ochraceous, which markings become broad shaft-streaks on the cervix and dwindle to narrow shaft lines on the interscapulum; tail chestnut; wings fuscous, when closed the exposed surface reddish olive brown, excepting the innermost secondaries which are entirely dark chestnut, and the inner margins

${ }^{1}$ Zoological Journal, II, 1825, p. 91.

${ }^{2}$ Edinb. New. Philos. Journ., New Ser., I, 1855, p. 244.

${ }^{3}$ Nouv. Dict. d' Hist. Nat., III, 1816, p. 312.

${ }^{4}$ Mus. Hein., II, 1859, p. 18. 
of the basal portions of the quills, which are fulvous; lores, cheeks, and superciliary stripe pale buff, the first mixed, the rest finely squamate with olive brown; auriculars ochraceous buff, on lower half mixed with olive brown, on upper portion dark brown mixed with buffy; sides of neck ochraceous, with squamate markings of dark olive brown; chin and throat deep buff, unmarked; rest of inferior surface dull grayish olive brown, much paler than the upper parts, and broadly streaked, particularly on median portion, with dull ochraceous buff, the crissum rather more rufescent; lining of wing ochraceous buff. "Iris brown."

The difference in size exhibited by the single specimen above described is so great that it seems not to be attributable to sex or age, but to indicate a geographical race worthy of recognition. The character of the dorsal markings is constant in the six Brazilian specimens examined. Both of the synonyms of Picolaptes tenuirostris--Dendrocopus fuscus Vieillot, ${ }^{1}$ and Picolaptes guttata Lesson, ${ }^{2}$ refer without doubt to the bird from Brazil, so that the Paraguay form is without a name.

The size of both tenuirostris and apothetus is shown in the following table of millimeter measurements:

\begin{tabular}{|c|c|c|c|c|c|c|}
\hline Name. & Sex. & Locality. & Wing. & Tail. & $\begin{array}{l}\text { Exposed } \\
\text { culmen. }\end{array}$ & Tarsus. \\
\hline 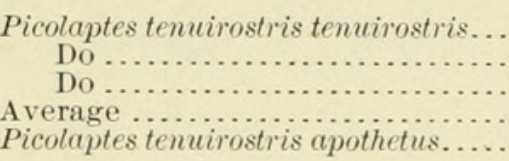 & $\begin{array}{l}\text { Male } . . . . \\
\text { Male?..... } \\
\text { Male?..... } \\
\text { Male....... }\end{array}$ & 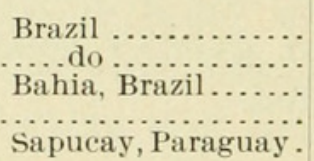 & $\begin{array}{l}79 \\
88 \\
84 \\
83.7 \\
74\end{array}$ & $\begin{array}{l}69 \\
71 \\
69 \\
69.7 \\
65\end{array}$ & $\begin{array}{l}23 \\
25 \\
27 \\
25 \\
22\end{array}$ & $\begin{array}{l}20 \\
19 \\
18 \\
19 \\
18\end{array}$ \\
\hline
\end{tabular}

\section{Family FURNARIIDÆ.}

\section{SITTASOMUS ERITHACUS (Lichtenstein).}

Dendrocolaptes erithacus Lichtenstein, Abhandl. Akad. Berl., 1820, p. 259, pl. I. Sittasomus erythacus BonaParte, Consp. Avium, I, 1850, p. 209.

The single example differs from one taken at Bahia, Brazil, in its deeper, more yellowish olive color both above and below. "Iris brown."

\section{XENICOPSIS ACRITUS (Oberholser).}

Anabazenops acritus Oberholser, Proc. Biol. Soc. Washington, XIV, 1901, p. 187. Xenicopsis acritus Oberholser, Proc. U. S. Nat. Mus., XXV, 1902, p. 61.

Chars. sp. - Similar to Xenicopsis oleagineus (Sclater), but decidedly darker, particularly below, the color throughout greenish olive instead of olive brown, the superciliary stripe deeper ochraceous, the throat more yellowish, the light areas of the lower surface more greenish.

${ }^{2}$ Cent. Zool., 1830, p. 93, pl. xxxII. 
Description.-Type, adult male, No. 173384, U.S.N.M.; Sapucay, Paraguay, June 14, 1900; William T. Foster. Upper surface almost uniform dull, dark olive green, many of the feathers with very narrow dusky margins producing a slight squamate effect; tail bright chestnut, unmarked; wings dark brown, the innermost secondaries, outer vanes of primaries and exposed surface of all the superior wing-coverts rufescent olive brown, the inner margins of all the quills deep ochraceous; lores and superciliary stripe rich ochraceous, the former mixed with olive, the latter somewhat paler posteriorly; sides of head and neck dull olive green, much streaked with yellowish and buffy white; chin and upper throat pale naples yellow, the feather's with small terminal spots of olive; rest of lower surface dull olive green, streaked with yellowish white, greenish white, and pale ochraceous, most broadly along the median line, most narrowly on flanks and sides where restricted to fine shaft lines, all this streaking distinct, as in Xenicopsis oleagineus; crissum with a rufous tinge; lining of wing dark ochraceous. "Iris brown." Length of wing, $75 \mathrm{~mm}$.; tail, $76 \mathrm{~mm}$.; exposed culmen, $16 \mathrm{~mm}$; tarsus, $23 \mathrm{~mm}$.; middle toe, $17 \mathrm{~mm}$.

This new species, of which but a single specimen is in the collection, is apparently most closely allied to Xenicopsis oleagineus (Sclater), ${ }^{1}$ but compared with some of the original specimens of that species it differs as above stated. With $X$. rufosuperciliatus (Lafresnaye) ${ }^{2}$ it can scarcely be confused, being so very different in its dull olive green instead of rufescent olive brown, both above and below, and in the very much more sharply defined markings of the ventral surface. Reichenbach's Cichlocolaptes ochroblephames ${ }^{3}$ and his Cichlocolaptes adspersus ${ }^{4}$ belong undoubtedly under Xenicopsis mifosupercitiatus, so that the present bird appears never to have been described.

The type of the genus Anabazenops is clearly Sitta fusca Vieillot (=Anabatoides fuscus Auct.) for which this name should be used, leaving, as Dr. Sharpe has indicated, ${ }^{5}$ Xenicopsis Cabanis and Heine for the group commonly known as Anabazenops.

\section{PHILYDOR RUFUS (Vieillot).}

Dendrocopus rufus Vieillot, Nouv. Diet. d'Hist. Nat., XXVI, 1818, p. 119.

Philydor rufus Cabanis and Heine, Mus. Hein., II, 1859, p. 29.

One specimen, apparently identical with a Brazilian example. "Iris brown."

${ }^{1}$ Proc. Zool. Soc. Lond., 1883, p. 654.

${ }^{2}$ Mag. de Zool., 1832, Ois., pl. vir.

${ }^{3}$ Handbuch der Spec. Orn., 1851, p. 174, pl. Dxxvir, fig. 3638.

${ }^{4}$ Idem, p. 174.

${ }^{5}$ Hand-List Gen. and Spec. Birds, III, 1901, p. 70. 


\section{ANUMBIUS ANNUMiBI (Vieillot).}

Furnarius annumbi Vieillot, Nouv. Diet. d'Hist. Nat., XII, 1817, p. 117.

Anthus acuticaudatus Lesson, Traité d'Orn., 1831, p. 424.

The one adult male in the collection seems to be just like specimens from Buenos Ayres. "Iris brown."

This well-known species, the Anumbius acuticaudatus of authors, should be called Anumbius annumbi, as above given, since this name is by several years the older, as well as of undoubted application.

\section{SYNALLAXIS SPIXI Sclater.}

Synailaxis spixi Sclater, Proc. Zool. Soc. Lond., 1856, p. 98.

The single example, an adult male, is apparently indistinguishable from the birds of Brazil which represent the typical form of the species. "Iris brown."

\section{SYNALLAXIS RUFICAPILLA Vieillot.}

Synallaxis ruficapilla Vienllot, Nouv. Dict. d'Hist. Nat., XXXII, 1819, p. 310.

One specimen, an adult female. "Iris brown."

\section{LOCHMIAS NEMATURA (Lichtenstein).}

Myiothera nematura Lichtenstern, Verz. Doubl., 1823, p. 43.

Lochmias nematura Bonaparte, Consp. Avium, I, 1850, p. 210.

The single specimen is rather darker, duller, and less rufescent above than one from Brazil, but otherwise does not differ. "Iris brown." There is a good deal of variation in color among examples of this species, but it seems to be entirely individual, not geographical.

\section{FURNARIUS RUFUS (Gmelin).}

Merops rufus Guelin, Syst. Nat., I, 1788, p. 465.

Furnarius rufus D’Orbigny, Voyage Amér. Mérid., Ois., 1835-44, p. 250.

One specimen; appreciably darker on the breast and upper parts than examples from Buenos Ayres; but whether or not this difference is geographical is inconclusively shown by the material at hand. "Iris brown."

\section{Family COTINGID A.}

\section{PACHYRHAMPHUS VIRIDIS (Vieillot).}

Tilyra viridis Vieillot, Nouv. Dict. d'Hist. Nat., III, 1816, p. 348.

Pachyrhamphus viridis Selater, Proc. Zool. Soc. Lond., 1857, p. 75.

A single adult male is in the collection. "Iris brown."

The basis of Vieillot's Tityra viridis was Azara's Paraguay bird, the present example coming thus from the type locality. The bird of eastern Brazil, however, is much smaller and slightly paler, being 
apparently separable as a geographical race. Five males from Bahia, Brazil, average in measurement of wing, $72 \mathrm{~mm}$., of tail, $56 \mathrm{~mm}$.; while the present Paraguay example has a wing of $78 \mathrm{~mm}$, and a tail of $62 \mathrm{~mm}$. The earliest name available for the Brazilian race is cuvier $\ddot{\text { Swainson: }}{ }^{1}$ and the proper combination is Pachyrhamphus viridis cuvierii.

\section{Family PIPRID A.}

\section{SCOTOTHORUS UNICOLOR (Bonaparte).}

Heteropelma unicolor Bonaparte, Consp. Av. Volucr. Anisod., 1854, p. 4. Scotothorus unicolor Oberholser, Proc. Acad. Nat. Sci. Phila., 1899, p. 209. Heteropelma virescens Auct.

One example, apparently typical. "Iris brown."

\section{CHIROXIPHIA CAUDATA (Shaw).}

Pipra caudata SHaw, Nat. Miscell., V, 1794, pl. clin.

Chiroxiphia caudata Cabanis, Wiegmann's Archiv f. Naturg., 1847, I, p. 235.

Three specimens. "Iris brown." One of these is an immature male, and differs from the adult female as follows: Whole crown scarlet; throat, sides of head and neck mixed with blackish; under surface tinged with bluish.

\section{Family TYRANNIDA.}

\section{MYIARCHUS FEROX (Gmelin).}

Muscicapa ferox Gmelin, Syst. Nat., I, 1788, p. 934.

Myiarchus ferox Cabanis, Wiegmann's Arehiv f. Naturg. (Ornith. Notiz.), I, 1847 , p. 248.

One specimen, closely resembling birds from Guiana, differing only in the more rufescent tinge to the upper tail-coverts, and in the darker, more reddish edgings to the wing-coverts. "Iris brown."

Judging from specimens in the United States National Museum collection, Myiarchus ferox is entirely distinct from Myiarchus pel$z e l n i$ Berlepsch. ${ }^{2}$ The latter is lighter ashy on the breast, much paler, more grayish above, and has a decidedly paler bill.

\section{BLACICUS PILEATUS (Ridgway).}

Contopus pileatus Ridgway, Proc. U. S. Nat. Mus., VIII, 1885, p. 21.

Blacicus pileatus OBerholser, Auk, XVI, 1899, p. 337.

A single adult male of this very distinct species is of particular interest, since it reveals for the first time the region in which the bird may be found. The species was originaliy described from a single specimen without indicated locality, which $\mathrm{Mr}$. Ridgway discovered among the collections of the American Museum of Natural History in 
New York City, and which until now has remained unique. The present example has been carefully compared with the type, and there is no doubt of their identity; though the former is somewhat more ochraceous on the central portion of the abdomen, as well as darker, slightly more greenish olive throughout, this difference, of course, to be expected, for the type was for a long time mounted, and through exposure to light has become somewhat faded. Our specimen measures: wing, $76 \mathrm{~mm}$; tail, $65 \mathrm{~mm}$; exposed culmen, $11 \mathrm{~mm}$.; tarsus, $13.5 \mathrm{~mm}$.; middle toe, $8 \mathrm{~mm}$. "Iris brown."

\section{SIRYSTES SIBILATOR (Vieillot).}

Muscicapa sibilator Vieillot, Nouv. Dict. d'Hist. Nat., XXI, 1818, p. 457.

Sirystes sibilator Cabanis and Heine, Mus. Hein., II, 1859, p. 75.

One female. "Iris brown." The edgings of the wing-coverts in this example are entirely ochraceous, apparently a lingering mark of immaturity. The longer lower tail-coverts are pale ochraceous, and the black upper tail-coverts are narrowly margined with chestnut.

\section{RHYNCHOCYCLUS SULPHURESCENS (Spix).}

Platyrhynchus sulphurescens SPIX, Av. Spec. Nov. Bras., II, 1825, p. 10, pl. xII, fig. 1. Rhynchocyclus sulphurescens Cabanis and Herne, Mus. Hein., II, 1859, p. 56.

One adult female, July 21, 1900. "Iris light brown."

This species is quite certainly divisible into several geographical races, but sufficient material is not at present accessible to render advisable any such attempt. Birds from Matto Grosso, Brazil, are identical with the one here chronicled from Paraguay, and those from Trinidad are not appreciably different.

\section{SUIRIRI SUIRIRI (Vieillot).}

Muscicapa suiriri Vieillot, Nouv. Dict. d'Hist. Nat., XXI, 1818, p. 487.

Suiriri suiriri D’Orbigny, Voyage Amér. Mérid., Ois., 1835-44, p. 336.

One adult female. "Iris brown." This is a typical specimen, as Vieillot's name was based on the "Suiriri ordinario" of Azara. The bird described by Gould as Pachyramphus albescens, ${ }^{1}$ from Buenos Ayres, good specimens of which are in the United States National Museum, represents a recognizable subspecies which should be known as Suiriri suirivi albescens. It differs from the true suiriri in being rather more grayish on the upper surface, but principally in having the wing-bars and outer margins of the secondaries almost pure white instead of dull olive gray.

The proper generic name for this group is Suiriri d'Orbigny, ${ }^{2}$ as it seems to be entirely pertinent, and of very much earlier date than Empidagra Cabanis and Heine. ${ }^{3}$

\footnotetext{
${ }^{1}$ Zool. Voyage Beagle, III, 1841, p. 50, pl. xIv.

${ }^{2}$ Voyage Amér. Mérid., Ois., 1835-44, p. 336.

${ }^{3}$ Mus. Hein., II, 1859, p. 59.
} 


\section{MYIOPAGIS CANICEPS (Swainson).}

Tyrannula caniceps Swainson, Birds Brazil, 1835 (?), pl. Xírx.

Myiopagis caniceps Sharpe, Hand-List Gen. Spec. Birds, III, 1901, p. 117.

A fine adult male of this very rare and very distinct species is in the collection. It differs in some respects from typical members of the genus Myiopagis in its more slender bill and greater relative length of the two outer primaries, but is undoubtedly much more satisfactorily placed here than in Elæxia. This specimen may be described as follows:

Crown plumbeous, with slaty shaft streaks and washed with olive green; the basal portion of the crest feathers white, mixed with pale sulphur yellow, forming a lengthened, almost concealed vertical spot; remainder of upper surface rather paler than the crown, olive green, brightest and clearest on rump, increasingly mingled with plumbeous anteriorly until completely merging into the color of the pileum; tail fuscous, bordered with olive green; wings sepia brown, the lesser coverts and outer margins of primaries olive green, the outer edges of secondaries, with tips of greater and lesser wing-coverts pale sulphur yellow; the sides of head and neck plumbeous, mixed with greenish on the latter, the auriculars with whitish shaft streaks, the eye ring and suborbital region mixed with gray ish white; lower surface dull white, the breast and sides of throat shaded with plumbeous, the sides, flanks and crissum tinged with sulphur yellow, this on the sides slightly mingled with greenish; lining of wing pale sulphur yellow; inner margins of wing-quills buffy white. "Iris buff." Length of wing, $59 \mathrm{~mm}$.; tail, $54 \mathrm{~mm}$.; exposed culmen, $9.5 \mathrm{~mm}$.; tarsus, $18 \mathrm{~mm}$.; middle toe, $11.5 \mathrm{~mm}$.

\section{ELÆNIA PAGANA PAGANA (Lichtenstein).}

Muscicapa pagana Lichtenstein, Verz. Doubl., 1823, p. 54.

Elaenea pagana Cabanis, in Schomburgk's Reis. Guian., III, 1848, p. 701.

One female. "Iris brown."

\section{PHYLLOMYIAS SALVADORII (Dubois).}

Phyllomyias berlepschi Salvadori, Boll. Mus. Torino, XII, 1897, No. 292, p. 13 (not Sclater).

Phyllomyias brevirostris var. salvadorii Dubors, Synop. Avium, Pt. 4, 1900, p. 238.

A single adult specimen belongs undoubtedly to this newly described species. It measures as follows: Wing, $62.5 \mathrm{~mm}$; tail, $60 \mathrm{~mm}$.; exposed culmen, $8 \mathrm{~mm}$; tarsus, $18 \mathrm{~mm}$; middle toe, $10.5 \mathrm{~mm}$. "Iris brown." 


\section{LEPTOPOGON AMAUROCEPHALUS ICASTUS Oberholser.}

Leptopogon amaurocephalus icastus Oberholser, Proc. Biol. Soc. Washington, XIV, 1901, p. 187.

Chars. subsp. - Similar to Leptopogon amaurocephalus tristis, but larger, crown more brownish, the anterior lower surface less purely yellow, and the wing-bands pale ochraceous instead of pure yellow.

Description.-Type, adult male, No. 173405, U.S.N.M.; Sapucay, Paraguay, July 23, 1900; William T. Foster. Crown and occiput olive brown, but little darker than the pure olive green of the remainder of the upper surface, and into which it almost insensibly passes on the nape; upper tail-coverts slightly more brownish than the back; tail fuscous, edged with olive green; wings sepia brown, the remiges margined externally with olive green, internally with buff, the lesser coverts olive green, the others edged with the same, the median and greater series with broad tips of pale ochraceous, forming two welldefined wing-bands; lores and orbital region brownish white, mixed with olive brown; cheeks mingled greenish, brownish, and whitish; auriculars anteriorly brownish white, posteriorly deep olive brown, this forming a conspicuous patch; sides of neck grayish olive green; chin and upper throat grayish white, washed with olive yellow; rest of ventral surface sulphur yellow, much shaded with olive green on jugulum, breast, and sides; lining of wing sulphur yellow, the bend of wing tinged with, ochraceous; bill brownish black, the basal half of mandible dull white. "Iris brown." Length of wing, $69 \mathrm{~mm}$; t tail, $63 \mathrm{~mm}$.; exposed culmen, $11 \mathrm{~mm}$.; tarsus, $16 \mathrm{~mm}$.; middle toe, $9 \mathrm{~mm}$.

This apparently new form is perhaps nearest Leptopogon amaurocephahs amaurocephalus, from which, however, it differs in its somewhat larger size, less ochraceous wing-bands, and paler, much less brownish, less well-defined cap.

Dr. Allen ${ }^{1}$ is seemingly quite right in asserting the close relationship of Leptopogon amaurocephalus, L. a. pileatus, and L. a.tristis, and considering them simply as geographical forms of one wideranging species. Leptopogon a pileatus may easily be distinguished from true amaurocephahus by its darker, more ochraceous lower surface, more yellowish green upper parts, and warmer brown pileum.

\section{ORCHILUS AURICULARIS (Vieillot).}

Platyrhynchos auricularis Vieillot, Nouv. Dict. d'Hist. Nat., XXVII, 1818, p. 16. Orchilus auricularis Cabanis and Heine, Mus. Hein., II, 1859, p. 51.

A single example is like one from Brazil, except for rather darker, richer colors above as weî as on sides of head and neck. The latter, however, may possibly be a female. "Iris brown." 
EUSCARTHMUS MARGARITACEIVENTER (D'Orbigny and Lafresnaye).

Todirostrum margaritaceiventer D'Orbigny and Lafresnaye, Synop. Avium, I, 1837 , p. 46.

Euscarthmus margaritaceiventris Sclater and Salvin, Proc. Zool. Soc. Lond., 1879, p. 612 .

One specimen in perfect plumage. "Iris buff."

There are possibly two species at present united by authors under $E$. margaritaceiventer. The above example agrees with the original description of margaritaceiventer in being distinctly, even conspicuously, streaked on chin, throat, and breast. Dr. Sclater, however, describes this species as being without streaking on the lower surface, ${ }^{1}$ though he fails to note that this is not in correspondence with the original description. If the birds prove really to be representatives of two forms, the name for the nonstreaked species is probably Euscarthmus wuchereri Sclater and Salvin, ${ }^{2}$ the diagnosis of which seems to indicate such a difference from true $E$. margaritaceiventer.

\section{MACHETORNIS RIXOSUS (Vieillot).}

Tyrannus rixosus VieIllot, Nouv. Dict. d'Hist. Nat., XXXV', 1819, p. 85. Machetornis rixosus Burmeister, Syst. Ueber. Vög. Bras., II, 1856, p. 514.

A single female; apparently identical with birds from Brazil and Buenos Ayres. "Iris brown."

\section{COPURUS COLONUS (Vieillot).}

Musicapa colonus Vieillot, Nouv. Dict. d'Hist. Nat., XXI, 1818, p. 448. Copurus colonus Cabanis and Heine, Mus. Hein., II, 1859, p. 41.

One adult male. " Iris brown." The head is rather more grayish than in the adult specimens available for comparison, but whether this is due to age or to geographical variation is not evident from our material.

\section{LICHENOPS PERSPICILLATA (Gmelin).}

Motacilla perspicillata Gmelin, Syst. Nat., I, 1788, p. 969.

Lichenops perspicillatus Gould, Zool. Voy. Beagle, III, 1841, p: 51, pl. Ix.

Two specimens. " "Iris buff [young male]; iris yellow [adult male]." This immature male is quite similar to the adult female, but is darker and is more broadly streaked on the upper parts, breast, and lower tail-coverts.

\section{KNIPOLEGUS CYANIROSTRIS (Vieillot).}

Muscicapa cyanirostris Vieillot, Nouv. Diet. d'Hist. Nat., XXI, 1818, p. 447.

Cnipolegus cyanirostris Bonaparte, Consp. Avium, I, 1850, p. 195.

Two specimens, apparently typical. "Iris red [adult male]; iris brown [adult female]."

${ }^{1}$ Cat. Birds Brit. Mus., XIV, 1888, pp. 78, 80.

${ }^{2}$ Nomenclator Avium Neotrop., 1873, p. 158. 


\section{Family TROGLODYTID E.}

TROGLODYTES MUSCULUS Naumann.

Troglodytes musculus Naumann, Vög. Deutschl., III, 1823, p. 724, table (Lichtenstein manuscript).

One specimen. "Iris brown." This bird belongs apparently to the dark race from southern Brazil, to which the name musculus is applicable. It is identical with another specimen from the Parana River, and much darker, more rufescent both above and below than the birds from Buenos Ayres.

Family VIREONID A.

\section{CYCLARHIS VIRIDIS (Vieillot).}

Saltator viridis Vieillot, Encyc. Méth., II, 1823, p. 793.

Cyclorhis viridis Burmeister, Syst. Ueber. Thiere Bras., III, 1856, p. 107.

One adult male. "Iris orange."

CYCLARHIS OCHROCEPHALA Tschudi.

Cyclarhis ochrocephala Tschudr, Wiegmann's Archiv f. Naturg., I, 1845, p. 362.

One specimen, an adult female. "Iris browny red."

\section{Family CORVIDA.}

\section{CYANOCORAX HECKELII Pelzeln.}

Cyanocorax heckelii Pelzeln, Sitz. k. Akad. Wiss. Wien, XX, 1856, p. 163.

A single unsexed, undated specimen of this rare and very handsome jay is in the collection. It is in excellent plumage and apparently entirely typical. Wing, $183 \mathrm{~mm}$.; tail, $159 \mathrm{~mm}$.; exposed culmen, $28.5 \mathrm{~mm}$.; tairsus, $46 \mathrm{~mm}$.

\section{Family CCEREBID A.}

DACNIS CAYANA (Linnæus).

Motacilla cayana Linnæus, Syst. Nat., 12th ed., I, 1766, p. 336.

Dacnis cayana Strickland, Contr. Orn., 1851, p. 15.

Two specimens, both of which seem to be rather darker and duller above than ordinary examples. "Iris light brown [male];" "iris brown [female]."

\section{ATELEODACNIS SPECIOSA (Maximilian.)}

Sylvia speciosa Maximilian, Beitr. Naturg. Bras., III, 1830, p. 708.

Two specimens. " Iris brown [male];" "iris light brown [female]." The male is not quite adult, having still a wash of yellowish olive on the upper parts, most of the wing-quills with yellowish green outer 
margins, and many pale buffy feathers on the under surface, where they contrast plainly with the incoming feathers of the pale gray perfect plumage.

Mr. Ridgway has directed our attention to the structural differences obtaining between the so-called "Dacnis" speciosa and Dacnis cayanadifferences that obviously necessitate generic separation, the name Ateleodacnis Cassin ${ }^{1}$ being applicable to the former. The other species of this group are:

Ateleodacnis leucogenys (Lafresnaye) (type of genus).

Ateleodacnis analis (d'Orbigny and Lafresnaye).

Ateleodacnis plumbea (Latham).

(?) Ateleodacnis salmoni (Sclater).

\section{Family MNIOTILTID A.}

\section{BASILEUTERUS AURICAPILLUS (Swainson).}

Setophaga auricapilla Swarnson, Anim. in Menag., 1837, p. 293.

Basileuterus auricapillus Sharpe, Cat. Birds Brit. Mus., X, 1885, p. 393.

One specimen. "Iris brown." The birds from northern South America are rather darker and decidedly more brownish above than those from Brazil and Paraguay, and are worthy of subspecific recognition.

This species is usually called Basileuterus vermivorus, but this name ${ }^{2}$ refers primarily to Sylvia vermivora Latham, ${ }^{3}$ which is Helmitherus vermivorus (Gmelin); and the designation above given is therefore the proper one.

\section{BASILEUTERUS LEUCOBLEPHARUS CALUS Oberholser.}

Basileuterus lucoblepharus calus OBerhoLser, Proc. Biol. Soc. Washington, XIV, 1901, p. 188.

Chars. subsp.- Similar to Basileuterus lencoblepharus lencoblepharus, but slate color of head and neck darker, less brownish; olive green of back and rump less yellowish; breast much more heavily shaded with slate gray; sides and flanks almost pure slate gray, instead of olive green mixed with pale brownish gray; crissum yellowish white instead of olive yellow; bill darker brown.

Description.-Type, adult male, No. 173448, U.S.N.M.; Sapucay, Paraguay, July 1, 1900; William T. Foster. Pileum and nape slate color; a sharply defined line extending backward from the base of bill on each side of the crown, slate black; rest of upper surface plain olive green; tail similar, with rather lighter edgings; remiges fuscous,

${ }^{1}$ Proc. Acad. Nat. Sci. Phila., 1864, p. 270.

${ }^{2}$ Sylvia vermivora Vieillot, Nouv. Dict. d'Hist. Nat., XI, 1817, p. 278.

${ }^{3}$ Index Orn., II, 1790, p. 544. 
all the exposed portions of the wings quite similar in color to the back; supraloral area and eye ring white; lores slate color; no well-defined superciliary stripe; cheeks, sides of throat and neck slate color, all but the last somewhat mixed with whitish; chin and center of throat white, sharply defined laterally and against the slate gray of the breast; center of the breast heavily mottled with slate gray, the sides of the same, together with sides of body and the flanks, deep slate gray, the latter very slightly mingled with olive green; median portion of abdomen white; under tail-coverts pale yellowish; bend of wing and axillars lemon yellow. Bill dark brownish slate; feet pale; "iris brown." Length of wing, $65.5 \mathrm{~mm}$.; tail, $67 \mathrm{~mm}$.; exposed culmen, $11 \mathrm{~mm}$; tarsus, $25 \mathrm{~mm}$.; middle toe, $14 \mathrm{~mm}$.

There seems to be little, if any, difference in size between calus and true leucoblepharus, but if anything, the former is slightly smaller. The only name which could by any possibility apply to this new form is Trichas superciliosus Swainson, ${ }^{1}$ and this appears to be undoubtedly a pure synonym of Basileuterus leucoblepharus leucoblepharus.

\section{GEOTHLYPIS ÆQUINOCTIALIS VELATA (Vieillot).}

Sylvia velata Vieillot, Ois. Amér. Sept., II, 1807, p. 22, pl. Lxxiv.

Geothlypis velata Cabanis, Mus. Hein., I, 1850, p. 16.

One specimen in perfect plumage, entirely typical of this form. "Iris light brown." Some specimens from western Brazil apparently indicate intergradation with auricularis, while others from the northeastern part of this country approach requinoctialis. There are at least four good subspecies of Geothlypis requinoctialis, as follows:

Geothlypis xquinoctialis xquinoctialis (Gmelin). - Northern South America, from Trinidad and Guiana to Colombia, and probably northeastern Peru.

Geothlypis xquinoctialis velata. (Vieillot).-Eastern and southern Brazil to northern Argentine Republic, southeastern Peru, and possibly Chile.

Geothlypis xquinoctialis auricularis (Salvin).-Western Peru.

Geothlypis æquinoctialis chiriquensis (Salvin).-Veragua, U. S. Colombia.

Although Sylvia cucullata Latham ${ }^{2}$ antedates Sylvia velata ${ }^{3}$ Vieillot for this species, to which attention has been called by Dr. Richmond, ${ }^{4}$ the combination Geothlypis cucullata can not be employed for this bird, since it was long previously used as the original designation of a Mexican bird described by Salvin and Godman. ${ }^{5}$

${ }^{1}$ Anim. in Menag., 1837, p. 295.

${ }^{2}$ Index Orn., II, 1790, p. 528.

${ }^{3}$ Ois. Amér. Sept., II, 1807, p. 22, pl. LXxiv.

${ }^{4}$ Auk, XVII, 1900, p. 179.

${ }^{5}$ Ibis, 1889, p. 237. 


\section{COMPSOTHLYPIS PITIAYUMI PITIAYUMI (Vieillot).}

Sylvia pitiayumi Vienllot, Nouv. Diet. d'Hist. Nat., XI, 1817, p. 276.

Compsothlypis pitiayumi CaBanis, Mus. Hein., I, 1850, p. 21.

One specimen, belonging without doubt to the typical form, rather than to the larger, darker and more richly colored race from northern and western South America, Compsothlypis pitiayumi pacifica. "Iris brown."

\section{Family ICTERID A.}

\section{ICTERUS PYRRHOPTERUS (Vieillot).}

Agelaius pyrrhopterus Vieillot, Nouv. Dict. d'Hist. Nat., XXXIV, 1819, p. 543. Icterus pyrrhopterus D'Orbigny and Lafresnaye, Synop. Avium, II, 1838, p. 6.

One adult male, apparently identical with Bolivian specimens. "Iris brown."

\section{Family TANAGRID E.}

\section{TRICHOTHRAUPIS QUADRICOLOR (Vieillot).}

Tachyphonus quadricolor VIEILlot, Nouv. Dict. d'Hist. Nat., XXXII, 1819, p. 359.

Trichothraupis quadricolor Cabanis, Mus. Hein., I, 1850, p. 23.

Two specimens. "Iris brown." The immature male of this species differs from the adult in being darker, more brownish olive above, and more deeply ochraceous below; the yellow coronal patch is wanting, but is indicated by the pale yellow bases of the feathers of the vertex, the amount of this color increasing with age.

\section{PHENICOTHRAUPIS RUBICA (Vieillot).}

Staltator [sic] rubicus Vieillot, Nouv. Dict. d'Hist. Nat., XIV, 1817, p. 107.

Phoenicothraupis rubica CaBanis, Mus. Hein., I, 1850, p. 24.

One specimen, an adult male, apparently typical. " Iris brown."

\section{NEMOSIA GUIRA (Linnæus).}

Motacilla guira Linneus, Syst. Nat., 12th ed., I, 1766, p. 335.

Nemosia guira Bonaparte, Consp. Avium, I, 1850, p. 236.

Two specimens, male and female. "Iris brown."

Birds from Paraguay and southwestern Brazil are uniformly of large size, while those from eastern South America (Brazil to Venezuela) seem to average smaller; but whether or not this character is sufficiently constant to warrant the recognition of two geographical races the present material does not show. There is no observable difference in color.

\section{EUPHONIA PECTORALIS (Latham).}

Pipra pectoralis Latham, Index Orn., Suppl., 1801, p. Ivii.

Euphonia pectoralis Bonaparte, Consp. Avium, I, 1850, p. 233.

One adult male. "Iris brown." 


\section{EUPHONIA VIOLACEA (Linnæus).}

Fringilla violacea Linneus, Syst. Nat., 10th ed., I, 1758, p. 182.

Euphonia violacea Maximilian, Beitr. Naturg. Bras., III, 1830, p. 439.

Two specimens, male and female. "Iris brown."

While there seems to be no constant color difference between birds from Guiana and those from southern Brazil and Paraguay, yet the northern race is so much smaller that its recognition by name is well deserved. Dr. Sclater considered ${ }^{1}$ the Guiana bird to be the typical form; but Linnæus' description, in so far as it is possible to determine, was based on the bird from Brazil, being, moreover, so considered by Cabanis when he separated the race from Cayenne; ${ }^{2}$ and consequently the latter is the one that should be called Euphonia violacea lichtensteini, unless, indeed, Lichtenstein's prior name be considered tenable, ${ }^{3}$ in which case it would stand as Euphonia violacea minor.

\section{CHLOROPHONIA CHLOROCAPILLA (Shaw).}

Pipra chlorocapilla Sнаw, Gen. Zool., XIII, Pt. 2, 1826, p. 255.

Tanagra viridis Vieillot, Nouv. Dict. d'Hist. Nat., XXXIi, 1819, p. 426.

Chlorophonia viridis Bonaparte, Rev. Zool., 1851, p. 137.

One specimen, an adult male, of which the colors are very rich, particularly the blue of the upper surface, this approaching indigo on the back. "Iris brown."

Vieillot's specific name viridis, commonly employed for this species, is preoccupied by Tanagra viridis Müller, ${ }^{4}$ which has been considered a synonym of Calospiza tatao. The proper name for Chlorophonia viridis Auct. is therefore as above given.

Family FRINGILLID \&.

\section{PYRRHOCOMA RUFICEPS (Strickland).}

Tachyphonus ruficeps Strickland, Ann. and Mag. Nat. Hist., XIII, 1844, p. 419. Pyrrhocoma ruficeps Cabanis, Mus. Hein., I, 1851, p. 138.

Two specimens, male and female. "Iris [of both] brown." The male is of a rather clearer slate color, both above and below, than examples from Brazil, and has a somewhat paler throat, though otherwise does not differ.

\section{CORYPHOSPINGUS CUCULLATUS (Müller).}

Fringilla cucullata MüLler, Syst. Nat., Anhang, 1776, p. 166.

Fringilla cristata GMelin, Syst. Nat., I, 1788, p. 926.

Two specimens, male and female. The latter is darker throughout than the three others of the same sex available for comparison. The iris of both sexes is given as brown by the collector.

${ }^{1}$ Cat. Birds Brit. Mus., XI, 1886, p. 74.

${ }^{2}$ Phonasca lichtensteini Cabanis, Journ. für Orn., 1860, p. 331.

${ }^{3}$ Euphonia violacea var. minor Lichtenstein, Verz. Doubl., 1823, p. 29.

${ }^{4}$ Syst. Nat., Anhang, 1776, p. 158. 
This species, the Coryphospingus cristatus of authors, should be called Coryphospingus cucullatus, as Müller's long-neglected name has a number of years priority.

\section{ARREMON CALLISTUS Oberholser.}

Arremon callistus Oberholser, Proc. Biol. Soc. Washington, XIV, 1901, p. 188.

Chars. sp.-Much like Arremon polionotus, but upper parts darker; black jugular band broader; wing without a yellowish olive green humeral patch; bend of wing white; size slightly larger.

Description.-Type, adult male, No. 173425, U.S.N.M.; Sapucay, Paraguay, July 22, 1900; William T. Foster. Pileum black, the occiput centrally slate color; rest of upper surface slate color; tail slate black, narrowly margined with slate; wings blackish slate, the quills edged with the color of the back, the exposed portions of secondary coverts entirely slate color, with a very slight yellowish olive wash on the lesser series, the alula and primary coverts black, the edge of the wing at the wrist white with a faint tinge of yellowish; sides of head black, a broad white stripe leading from above the eve on each side to the nape; sides of neck slate color; entire under surface white, the jugulum with a rather (10 millimeters) wide black band, reaching laterally halfway up the sides of the neck; sides of breast slate color; sides of body, flanks and lining of wing slate gray, the last with also some white and some slate color. Mandible and basal half of maxillar tomia yellowish orange, remainder of maxilla black; "iris brown." Length of wing, $80 \mathrm{~mm}$.; tail, $73 \mathrm{~mm}$.; exposed culmen, $12.5 \mathrm{~mm}$.; tarsus, $24 \mathrm{~mm}$.; middle toe, $16.5 \mathrm{~mm}$.

The above-described specimen, which is the only one sent by $\mathrm{Mr}$. Foster, differs so much from all of a large series of Arremon polionotus with which it has been compared that it seems impossibly identifiable with that species. The discrepancies are not such as can be attributed to sex, age, or even to individual peculiarity; the bird is undoubtedly an adult male, and as such has been treated. With species other than polionotus it needs no comparison.

\section{EMBERIZOIDES MACROURUS HERBICOLA (Vieillot).}

Sylvia herbicola Viemllot, Nouv. Dict. d'Hist. Nat., XI, 1817, p. 192.

Emberizoides herbicola Sharpe, Cat. Birds Brit. Mus., XIII, 1888, p. 769.

One specimen, an adult female. "Iris light brown." This form is apparently well entitled to subspecific recognition, for though but little different in size, the almost invariably unstreaked crissum serves for its easy recognition.

\section{EMBERNAGRA PLATENSIS (Gmelin).}

Emberiza platensis Gmelin, Syst. Nat., I, 1788, p. 886.

Embernagra platensis D’Orbigny, Voyage. Amér. Mérid., Ois., 1835-44, p. 284.

The single specimen is rather more grayish above and less buffy Proc. N. M. vol. $\mathrm{xxv}-02-10$ 
below than examples from Buenos Ayres, but this is probably due to its fresh plumage. "Iris brown."

\section{MYOSPIZA MANIMBE (Lichtenstein).}

Fringilla manimbe Lichtenstein, Verz. Doubl., 1823, p. 25.

One example, an adult male in freshly molted plumage. "Iris brown." There seem to be absolutely no constant characters to support the separation of the birds of this region as a subspecies dorsalis. ${ }^{1}$

\section{BRACHYSPIZA CAPENSIS CAPENSIS (Müller).}

Fringilla capensis Müller, Syst. Nat., Anhang, 1776, p. 165.

Brachyspiza capensis RIDGWAY, Auk, XV, 1898, p. 321.

One specimen, an adult male. "Iris light brown."

\section{SYCALIS PELZELNI Sclater.}

Sycalis pelzelni Sclater, Ibis, 1872, p. 42.

One specimen in fresh plumage. The flanks and sides are very obscurely streaked, and the dull pectoral band is conspicuous. The orange yellow of the forehead is much obscured by dusky. "Iris brown."

\section{SPOROPHILA ALBOGULARIS (Spix).}

Loxia albogularis SPIX, Av. Gen. et. Spec. Nov. Bras., II, 1824, p. 46, pl. LX, figs. 1,2 .

Sporophila albogularis CaBanis, Mus. Hein., I, 1851, p. 149.

A single female Sporophila belongs apparently to this species. "Iris brown.'

\section{CYANOLOXIA GLAUCOCÆRULEA (d'Orbigny).}

Pyrrhula glaucoxrulea D’Onbigny, Voy. Amér. Mérid., Ois., 1835-44, pl. t, fig. 2. Cyanoloxia glaucocaerulea Bonaparte, Consp. Avium, I, 1850, p. 503.

Two specimens. "Iris brown." One of these is an immature male just beginning to assume the blue plumage of the adult, in which condition it is paler below than the adult female. The other example is an adult female, but is darker, particularly above, than another of the same sex, in this approaching Cyanocompsa sterea, though in other respects remaining typical of $C$. glancoccerulea.

\section{CYANOCOMPSA STEREA Oberholser.}

Cyanocompsa sterea Oberholser, Proc. Biol. Soe. Washington, XIV, 1901, p. 188.

Chars. sp.-Similar to Cyanocompsa cyanea, but bill much smaller; the blue of forehead and crown less purplish; the female much deeper, less rufescent brown, particularly on the upper surface.

\footnotetext{
${ }^{1}$ Ridgway, Hist. N. Am. Land Birds, I, 1874, p. 549.
} 
Description.-Type, immature male, No. 173416, U.S.N.M.; Sapucay, Paraguay, July 21, 1900; William T. Foster. Upper parts deep umber brown, rather paler on nape and rump, more rufescent on the latter; crown and forehead dull blue, the forehead lighter and more greenish; wings and tail sepia brown, the wing-coverts and outer margins of the wing-quills like the back, some blue like that of the head showing on the bend of the wing; sides of the head and neck dull deep brown, with some admixture of bluish, the lores deep buff; entire under surface brown, much paler and more rufescent than that of the upper parts, lightest on the chin and middle of the abdomen. Wing, $73 \mathrm{~mm}$.; tail, $67 \mathrm{~mm}$; exposed culmen, $12 \mathrm{~mm}$.; depth of bill at base, $10.5 \mathrm{~mm}$.; tarsus, $18 \mathrm{~mm}$.; middle toe, $14.5 \mathrm{~mm}$.

A female taken June 23,1900 , is quite similar to the immature male, except for the lack of all bluish trace, and being of a noticeably more rufous hue throughout. Wing, $71 \mathrm{~mm}$.; tail, $65 \mathrm{~mm}$.; exposed culmen, $12.5 \mathrm{~mm}$.; depth of bill at base, $10 \mathrm{~mm}$.; tarsus, $21 \mathrm{~mm}$.; middle toe, $15 \mathrm{~mm}$.

The two specimens of this new species have been carefully compared with a good series of Cyanocompsa cyanea from various parts of its range, and they are certainly distinct. Unfortunately the male is not adult, but enough of blue shows on the head and bend of the wing to indicate a color as well as a size difference from Cyanocompsa cyanea. Compared with Cyanocompsa glaucoccemulea it has a very much larger and differently shaped bill, though in other dimensions there seems to be no material difference; what there is of blue color is darker, decidedly less greenish; the female is also much more deeply colored throughout. In fact this new species is in nearly all of its characters to some extent intermediate between Cyanocompsa cyanea and Cyanoloxia glaucoccerulea. 


\section{$2 \mathrm{BHL}$ Biodiversity Heritage Library}

Oberholser, Harry C. 1902. "List of birds collected by William T. Foster in Paraguay." Proceedings of the United States National Museum 25(1281), 127-147. https://doi.org/10.5479/si.00963801.1281.127.

View This Item Online: https://www.biodiversitylibrary.org/item/32399

DOI: https://doi.org/10.5479/si.00963801.1281.127

Permalink: https://www.biodiversitylibrary.org/partpdf/9152

\section{Holding Institution}

Smithsonian Libraries

\section{Sponsored by}

Smithsonian

\section{Copyright \& Reuse}

Copyright Status: NOT_IN_COPYRIGHT

This document was created from content at the Biodiversity Heritage Library, the world's largest open access digital library for biodiversity literature and archives. Visit BHL at https://www.biodiversitylibrary.org. 